\title{
Cobac Control Measures on the Performance of MFIs
}

\section{Dr. Nkiendem Felix, Gahmuti Roland N., Felix Nyuysemo Ayenika, Fokeng Sylvie, Nchitu Polycarpe Asah}

\author{
Department of Marketing and Organisation, University of Dschang \\ Engineering in Applied Mathematics in Social Sciences, University of Yde II Soa \\ Department of Management and Marketing, University of Yde II Soa \\ Department of Management and Marketing, University of Yde II Soa \\ Department of Management and Marketing, University of Yde II Soa \\ BP. 4441 Yaounde
}

\begin{abstract}
Globally, the emergence of MFIS presents an unprecedented opportunity to extend financial services to the vast majority of the population. In Cameroon, MFIs and banks are governed by a series of enactments (conventions, laws, ordinance, presidential decrees, ministerial orders and circulars). Cobac control measures are becoming increasingly important to the performance of microfinance institutions in Cameroon. This measures seems to be indispensible for customer satisfaction as a measure of performance. We therefore set out to verify the level to which these measures influence the performance of microfinancial institutions. Data was collected from 160 respondents in the northwest and littoral regions in Cameroon. Measures of dispersion were studied including inferential statistics in terms of person correlation, test of hypothesis, analysis of variance, chi square. Our results show that COBAC control measures positively influence the performance of MFIs. Thus MFIs should re-enforce the implementation of COBAC control measures instead of considering them as threats.
\end{abstract}

\section{Key Words: COBAC Control measures, Performance, MFIS}

\section{Introduction}

A great portion of the economy of CEMAC is finance to a great extent by Micro Finance Institutions (MFIs). In sub Saharan Africa, MFIs helps to develops countries and boosting of entrepreneurship development especially amongst the low income earners (George et al, 2000). These institutions according to Eoin (2005a as in Schreiner and Colombet, 2001) attempt to improve access to small deposits and small loans for poor households neglected by banks. Thus, Rhyne (2001) argued that the main products and services of these institutions consists of providing microcredit's, subsidizing collateral through group leading guarantees or compulsory savings, disbursing more larger and repeated loans to customers depending on their repayment capabilities, monitoring loans disbursed to customers and safeguarding customers saving. Hence, different types of MFIs exists as savings and credit cooperatives, NGOs, programmes established by international organizations, legally-recognized micro-finance institutions, and micro-finance banks and their sizes greatly vary from 100 clients to over 6 million clients for the largest (Micro World, 2010-2016). According to Chiyah (2010a), informal financial institutions are village banks, cooperative credit unions, and social venture capital funds among others that assist in the financial needs of the society. MFIs often include both financial and social intermediation and execute activities as small loans working capital, informal appraisals of borrowers and investment, collateral substitutes (as compulsory saving, groups guarantees), access to repeat and larger loans based on repayment performance, streamlined loan disbursement, monitoring and secure saving product (Sayed et al, 2013).

\section{Literature Review}

\section{COBAC control measures on MFIs}




\section{Prudential regulations}

Prudential stands for licensed MFIs (Joselito et al, 2005). Prudential regulations aimed specifically at protecting the financial system as a whole as well as protecting the safety of small deposits in individual institutions into considerations capital adequacy, relaxation of unsecured leading limits, loan loss provisions, loan documentation among others (Seth, 2009a). Thus, good and better theories of prudential regulation consists of Marcro-prudential and Micro-prudential according to this author. Macro-prudential is concerned with the stability of the financial system in general whereas; Micro-prudential is deals with the health of the individual deposit taking institutions (David et al. 2010).

\section{Non-prudential regulations}

Non-prudential regulations comprise a variety of issues that determinate how MFIs need to be conducted as consumer protection, prevention of fraud and financial crimes, implementation of credit bureaus, transparent disclosure of interest rate to customers (Christen et al, 2003). Non-prudential rules also stands for screening out unsuitable owners or managers or requiring transparent reporting and disclosure-tend to be easier to administer because state authorities do not have to take responsibility for the financial soundness of the organisation (Richard, 2003). Non-prudential regulations issues span a series of spectrum as enabling the formation and operation of Micro leading institutions, protecting consumers, preventing fraud and financial crimes, setting up credit information services among others (B. Seth, 2009b).

\section{Prudential and Non-Prudential Standards for Regulating MFIs}

According to the Word Bank (2012b) standards for regulating MFIs, these institutions are classified in terms of what MFIs stands for in terms of financial inclusion as a regulatory objective, prudential and nonprudential regulation among others. This Bank further illustrate that prudential norms are make up of capital adequacy, capital adequacy for financial cooperatives and their networks, unsecured leading limits and loanloss provisions, governance, liquidity and foreign exchange risk, load documentation, reserves aganist deposits, reporting, restrictions on co-signers as borrowers, deposit insurance among others. Thus, other prudential supervision issues are deposit-taking Microfinance in terms of supervision cost, location of MFI supervisory function (e.g. within existing supervisory authority, delegated supervision, self-regulation and supervision, supervision of financial cooperatives and case of small member-based intermediaries) following World Bank report cited earlier etc.

\section{Prudential Ratios and Impact \\ Solidarity Funds as a percentage of capital}

This fund is established to assist member organizations in emergencies as natural deserter, war, famine and life threatening situations. This fund is always established with voluntary contributions from members of organizations. At the EI World Congress in 1998, the role of the Solidarity Fund was extended to provide financial support for development cooperation activities with member organizations in developing countries. The decision of the EI Congress opened the way for the Fund to not only be reactive to emergency situations, but to also be pro-active by cooperating with teacher organizations in developing countries and countries in transition. The Congress also decided that EI and its member organizations should be invited to allocate $0.7 \%$ of their annual income to this work. EI contributes $0.7 \%$ of its annual income to the Solidarity Fund. (ref). According to Solidarity Capital Group (2017), solidarity funds as capital is used to help the marginalized who are in need of their community. Solidarity Capital Group assists visionary management teams that are addressing many of society's toughest and most persistent social and environmental challenges. Their focus areas include community and economic development, sustainable agriculture, energy and environmental solutions, and social finance. For MFIs in the CEMAC Region, COBAC who is a regulating body stipulated $40 \%$ of solidarity funds as a percentage.

\section{Obligatory Reserves Norms}

Reserve ratio is very important for MFIs to keep as stipulated by COBAC with a percentage of $40 \%$. According to Gay (2011), MFIs keep reserves for three reasons.

Prudential: In most cases, looking at the goldsmith era, when commercial banks' ability to take deposit and issue their own banknotes was constrained by a requirement to hold proportionate reserves balances 
either directly or at another bank. These reserves help as guard or protection against solvency and liquidity risk.

Monetary Control: this can be in two forms, firstly, if reserves can be increased easily, the ratio can affect MFIs balance sheet growth. Secondly, the central bank could vary the level of return reserve rates in order $t$ in a way intended to influence the spread between lending and deposit on rates in order to impact the growth of monetary aggregate and inflation.

Liquidity Management: it can be passive or active using the reserve returns actively, the central bank surplus reserves by administrative fiat, so that the impact of a bank behavior does not in turn leads to inflation or deflation. Similarly, if demand for reserve exceeds supply, the central bank could lower reserves in response. a passive approach could br adopted, if reserves can be meet on an average over a period. Short term liquidity management by the MFIs is facilitated with a short term liquidity management by the MFIs which is facilitated with a short term interest rate.

\section{History of MFIs in Cameroon}

In Cameroon, MFIs can be traced as far back as 1963 when the first credit union was established at Njinikon in the North West Region, and as union members continues to multiply, in 2000, the banking Commission estimated that the number of MFIs operating in Cameroon was 652 and today numbered/estimated at 645 both registered and unregistered MFIs (Leonard, 2012a). However, in 1998 the Law 98/99 was passed to recognize MFIs as entities' within the financial domain and placed under the control of the Ministry of Finance than Ministry of Agriculture. Following this Law, COBAC was officially recognized as an authority to figure out MFIs and capable of dissolving them if they did not adhere to COBAC rules and regulations. Finally, in 2002, regulation number 01/02/CEMAC/UMAC/COBAC clearly defines and controls the activities of MFIs in Central Africa including Cameroon (Ian, 2009).

Following the 1980s crises in Cameroon that resulted to the closure of many branches of commercial and developmental banks in rural areas and some cities, top executives lost their jobs and later formed cooperative credit unions and functions as mini-banks (Leonard, 2012). Hence with the expansion of MFIs in Cameroon, roles of different stakeholders became visible and resulted to the Network of MFIs made up of institutions developed endogenously as MC2, CAMCCUL (Cameroon Cooperative Credit Union League), the Self Directed village Savings and Credit (CVECA) supported through the decentralized rural credit project of the Ministry of Agriculture and Rural Development with the support of BICEC and two other French institutions and two independent MFIs created by individuals and located mostly in urban areas (Leonard, 2012).

The development of microfinance has a number of obstacles in Cameroon as;

- Regulation in CEMAC region and in Cameroon caught in between different laws as the national law, the CEMAC law/COBAC and the OHADA law,

* There is clear absence of governance in the management of microfinance,

* Many MFIs neither have legal nor fiscal security,

* Problems of liquidity and as such are unable to satisfy $5 \%$ of the customers,

* MFIs are not yet subject to a real licensing procedure,

* The problem of increasing gap between COBAC's missions and its resources is worrisome as is the threat to its independence due to the role retained by the national authorities in banking supervision,

* Serious problem of resources continues to hamper COBAC's work a phenomenon exacerbated by the multiplication of tasks (i.e., supervision of microfinance, norms on internal controls and antimoney laundering) among others according to (Leonard, 2012).

MFIS have promoted credit and banking services to poor Cameroonians by increasing expansion to these institutions in the past years and is underpinned with disorder of regulatory landscape which remains poor, quacks within the sector, dubious MFIs running away with meager savings of the poor (Leonard, 2012). According to Eoin (2005 as in UNCDF, 2004), MFIs plays three roles in development especially in assisting very poor households meet basic needs. Microfinance offers a mechanism by which organizations as banks, nongovernmental organizations (NGOs), non-bank financial institutions (NBFIs) and governments offer financial services (loans, savings, money transfer services and micro insurance) to the poor (Aryeetey, 2008). 
The master framework that regulates microfinance activities in CEMAC came into force in 2002 known as "Standard $\mathrm{n}^{\circ}$ 01/02/CEMAC/IMAC/COBAC organization and supervising MFIs activities in the CEMAC". However, COBAC does not prescribe any legal form for MFIs but instead focuses on the nature of the activities. It defines microfinance as "activities undertaken by authorized entities that are neither banks nor financial institutions but take savings or deposits, give out credits or loans and offer specific financial products to those generally excluded from banking networks"(Mamouda, 2009). Thus many MFIs offers three services as accepting micro savings, micro credits, and carry out money transfers and others services such as micro insurance, mobile money and other social services are still at the developmental and experimental stage(Leonard 2012).

\section{Impact of COBAC regulations on MFIs}

In CEMAC zone, challenges of COBAC control measures on MFIs constitutes potential collisions of goals among classical banks and MFIs and between regional institutions, national ones and MFIs, bottlenecks, institutional duplications are other factors among others (Mamouda, 2009b). Whereas in Pakistan, MFIS do envisaged the problem of increasing competition, innovation and diversified products, profitability, stability, improper regulations, limited management capacity of MFIs (Muhammad, 2010). Hence, since 1970 irrespective of COBAC control mechanism on MFIs, MFIs in 1990s after a decade of economic recession encountered tremendous problems as poor management, inadequate skilled personnel, weak legal systems ground most institutions to a halt, fuzzy business strategies, non-alignment of policies with market realities, poor internal control and violation of basic principles of basic principles of financial risk management or simply poor knowledge of the mechanics of modern finance have been cited as some of the reasons illustrating causes of financial sector crises within the CEMAC (Mamouda, 2009c).

COBAC text also recommends each MFI to be part of the national association of MFIs as the National Association of Microfinance Institutions in Cameroon (ANEMCAM), Association des Professionnels des Etablissements de Microfinance (APEMF-CA) in Central Africa Republic among others according to (Claire, 2009b). Gilbert (n.d), COBAC envisages problems as limited resources, large geographical area of coverage; two regulators may create discrepancies with the demarcation of jurisdictions, irrespective of banks regular reports to COBAC and Ministry of Finance in terms of assets, liabilities, income, dividend, ownership, foreign exchange among others, these regulators often make unannounced visits to banks. COBAC regulations on MFIs has positively impacted lives of many households as leverage their activities by creating linkages with banks as a source of wholesale finance towards poverty alleviation, empowers women and reduces their marginalization in the socio-economic system, reduce poverty in households in form of savings and credit in the hands of the poor and permits run microenterprises and build assets etc (UNO, 2013b). According to Littlefield et al (2003), "there is abundant support to demonstrate that MFIs can lift families out poverty and is also able to contribute to the completion of six of the Eight Millennium development goals".

\section{Methodological Issues}

In this research work, the researcher had as main objectives to assess the effect of COBAC control measures on the performance of MFIs in the North West and Littoral Regions of Cameroon. The specific hypotheses were four in number. The first was to examine the effect of the risk coverage control measures on the performance of MFIs. The second was to assess the impact of the credit control measures on the performance of MFIs. The third was to evaluate the effect of the asset coverage control measures on the performance of MFIs, fourth was to verify if liquidity control measures has an effect on the performance of MFIs and lastly to what is the impact of obligatory reserve measures on the performance of MFIs?

Data analysis for this study involved two major steps: the data reduction process and the structural relationship analysis. The data reduction process aimed to reduce the number of variables and parameters in the research model to a manageable number in terms of the ratio between sample size and parameters estimated in the structural equation modeling (SEM). The structural relationship analysis would be used to establish models for the Ordinal Regression analyses to examine the relationship between COBAC control measures and performance. The data reduction process was conducted in order to reduce the constructs employed in this study into composite variables. 10 constructs (Solidarity funds as a percentage of Capita, 
Obligatory reserves control norms, Risk coverage control measures, Assets coverage control measures, Administrators, management and employees engagement control norm, Credit /resource ratio or transformation control measures, Ratio relative to line of financing received control measure, Liquidity control Ratio, Ratio of highest debtor-Highest debtor as a percentage of total debt control measure and Limit of other activities carried out control measures ) constituted COBAC control measure latent variables, and 10 constructs of performance (Profitability, customer satisfaction, bank liquidity, growth prospects, credit quality, distributable profits, risk exposure, credit strength, high amount of loans, distributable profit per share ). These 10 constructs were subjected to validity and reliability tests before a single score could be calculated to represent each construct. Confirmatory factor analysis (CFA) using SPSS-20 (statistical package for social sciences) was employed for examining construct validity of each scale by assessing how well the individual item measured the scale. During this process, 5 items of COBAC control norm were retained and 4 items of performance were retained. The goodness of fit indices (GFI) of the 5 constructs exceeded the 0.9 criterion that are required in establishing the construct validity. The reliability analysis was conducted by calculating the Cronbach's alpha for each scale. The result shows that the Cronbach's alpha measure for the constructs did not exceed the threshold point of 0.7 suggested by Nunnally (1967), but were at least $60 \%$ and this is encouraging given that the constructs are still in the exploratory stage. The final results of construct validity and reliability tests of the constructs are reported in this work. Having met the requirement of construct validity and reliability, the composite measure of each construct can be measured by calculating their mean values (Hair et al., 1998) and the models were given as shown below.

\section{Model one (1)}

Profitability $\left(\mathbf{Y}_{\mathbf{P}}\right)$ and Credit Risk Management Practices

$Y_{\mathrm{P}(1 \mathrm{t})}=\beta_{0}+\beta_{11} X_{\mathrm{RCCM}(1 \mathrm{t})}+\beta_{12} \mathrm{X}_{\mathrm{CCM}(2 \mathrm{t})}+\beta_{13} \mathrm{X}_{\mathrm{LCM}(3 \mathrm{t})}+\beta_{14} \mathrm{X}_{\mathrm{ACCM}(4 \mathrm{t})}+\beta_{15} \mathrm{X}_{\mathrm{ORCM}(5 \mathrm{t})}+\mu_{1 \mathrm{t}}$

\section{Model two (2)}

Customer satisfaction $\left(\mathbf{Y}_{\mathbf{C S}}\right)$ and Credit Risk Management Practices

$\mathrm{Y}_{\mathrm{BS}(2 \mathrm{t})}=\beta_{0}+\beta_{11} \mathrm{X}_{\mathrm{RCCM}(1 \mathrm{t})}+\beta_{12} \mathrm{X}_{\mathrm{CCM}(2 \mathrm{t})}+\beta_{13} \mathrm{X}_{\mathrm{LCM}(3 \mathrm{t})}+\beta_{14} \mathrm{X}_{\mathrm{ACCM}(4 \mathrm{t})}+\beta_{15} \mathrm{X}_{\mathrm{ORCM}(5 \mathrm{t})}+\mu_{1 \mathrm{t}}$

\section{Model three (3)}

\section{Bank Solvency ( $\left.\mathbf{Y}_{\mathrm{BS}}\right)$ andCredit Risk Management Practices}

$$
\mathrm{Y}_{\mathrm{CQ}(3 \mathrm{t})}=\beta_{0}+\beta_{11} \mathrm{X}_{\mathrm{RCCM}(1 \mathrm{t})}+\beta_{12} \mathrm{X}_{\mathrm{CCM}(2 \mathrm{t})}+\beta_{13} \mathrm{X}_{\mathrm{LCM}(3 \mathrm{t})}+\beta_{14} \mathrm{X}_{\mathrm{ACCM}(4 \mathrm{t})}+\beta_{15} \mathrm{X}_{\mathrm{ORCM}(5 \mathrm{t})}+\mu_{1 \mathrm{t}}
$$

\section{Data Analysis And Results}

We can see the descriptive statistics of a sample of the COBAC control measures that were used in the dissertation including a measure of their mean and standard deviation

The Mean shows the average value of the sample and the Standard deviation is a widely used measurement of variability or diversity used in statistics and probability theory. It shows how much variation exists in the sample variables. A low standard deviation indicates that the data points tend to be very close to the mean, whereas high standard deviation indicates that the data is spread out over a large range of values.

\section{KMO and Bartlett's Test}

\begin{tabular}{|l|l|l|}
\hline KMO and Bartlett's Test \\
\hline Kaiser-Meyer-Olkin Measure of Sampling Adequacy. & .293 \\
\hline \multirow{4}{*}{ Bartlett's Test of Sphericity } & Approx. Chi-Square & $\mathbf{3 7 9 . 0 9 5}$ \\
\cline { 2 - 3 } & Df & $\mathbf{4 5}$ \\
\cline { 2 - 3 } & Sig. & .000 \\
\hline
\end{tabular}


KMO \& Bartlett's Test is a measure of sampling adequacy that is recommended to check the ratio of the variable for the analysis being conducted. In most academic and business studies, KMO \& Bartlett's test play an important role for accepting the sample adequacy and the KMO test ranges from 0 to 1 .

Significance level at 0.000 which is less than 0.05 is acceptable, and in turn this denotes that opinions of respondents are positive, that is they agree that the COBAC control measures has an impact on performance.

\section{KMO $=0.00<0.05$}

Therefore, the variables used are adequate and reliable.

\section{Determination of the Eigen values for extraction}

After EFA and reliabilityanalysis, the final measurement instrument included 5 COBAC control measures items and 3 performance measurement items. As clearly noticed from Tables bellow that the 5 variable of COBAC control measures explained $\mathbf{7 8 . 9 6 9}$ percent of the total variance

\section{Correlations}

$\begin{array}{llll}\text { CCM } & \text { ACCM } & \text { LCM } & \text { ORM }\end{array}$

RCCM

Risk Coverage Measures(RCCM)

Credit Control Measures(CCM)

Asset Coverage Control

Measures(ACCM)

Liquidity Control Measures(LCM)

Obligatory Reserve Measures(ORM)

\section{1}

$.691^{* *} \quad 1$

$.666^{* *} \quad .413^{* *} \quad 1$

$.322^{* *} \quad .231^{*} \quad .384^{* *} \quad 1$

$\begin{array}{lllll}.581^{* *} & .541^{* *} & .727^{* *} & .215^{*} & 1\end{array}$

\footnotetext{
**. Correlation is significant at the 0.01 level (2-tailed).

*. Correlation is significant at the 0.05 level (2-tailed).
}

The above table shows the correlation coefficients for each field, the average of the part, correlation coefficients denoted significance at $(0.01,0.05)$, which means a content reliability for what is being measured.

\section{RELIABILITY STATISTICS}

\begin{tabular}{lll}
\hline \hline Cronbach's Alpha & $\begin{array}{l}\text { Cronbach's Alpha Based on } \\
\text { Standardized Items }\end{array}$ & No of Items
\end{tabular}

We can see that Cronbach's alpha is $0.631,(0.631>0.50)$ which indicates that there is internal consistency for our scale with this specific sample. 
After EFA and reliability analysis, the final measurement instrument included 3 performance measurement items which explained 82.521 percent of the total variance. Specifically, profitability explained 42.889 percent of the total variance, customer satisfaction explained 17.204 percent, loan performance explained 11.576 percent of the total variance and bank solvency explained 10.853 percent of the total variance

TABLE 4.4.5: CORRELATIONS

\begin{tabular}{lcccc}
\hline \hline & FP & CS & LP & BS \\
\hline PROFITABILITY(P) & $\mathbf{1}$ & & & \\
CUSTOMER SATISFACTION(CS) & $\mathbf{. 8 4 6 ^ { * * }}$ & $\mathbf{1}$ & & \\
BANK SOLVENCY(BS) & $\mathbf{. 3 5 5 ^ { * * }}$ & $\mathbf{. 3 8 3}^{* *}$ & $\mathbf{. 1 4 7}$ & $\mathbf{1}$ \\
\hline \hline
\end{tabular}

\section{TABLE 4.4.6: RELIABILITY STATISTICS}

\begin{tabular}{lll}
\hline \hline Cronbach's Alpha & $\begin{array}{l}\text { Cronbach's Alpha Based on } \\
\text { Standardized Items }\end{array}$ & N of Items
\end{tabular}

\section{.643}

.684

4

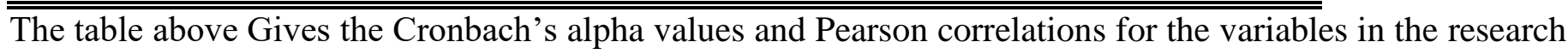
model. All factor loadings were greater than or equal to 0.50 thresholds.

This means that construct validity of the measures were satisfied. Cronbach's alpha values of the factors were high. This showed that all COBAC control measures and performance scales had acceptable reliabilities. This table indicates that the regression model predicts the outcome variable significantly very well. Looking at the "Regression" row and go to the Sig. column. This indicates the statistical significance of the regression model that was applied. Here, $\mathrm{p}<0.0005$, which is less than 0.05, and indicates that, overall, the model applied can statistically significantly predict the outcome variable.

\section{Testing the significance of the model using the ANOVA table}

This table of ANOVA above indicates that the regression model predicts the outcome variable significantly well from the Sig. column. This indicates the statistical significance of the regression model that was applied. Here, $\mathrm{p}<0.0005$, which is less than 0.05 , and indicates that, overall, the model applied can statistically significantly predict the performance variable outcome

\begin{tabular}{|c|c|c|c|c|c|c|}
\hline \multicolumn{7}{|c|}{$\begin{array}{l}\text { Model One } \\
\text { ANOVA FOR MODEL } 1 \\
\end{array}$} \\
\hline$\overline{\text { Model }}$ & & $\begin{array}{l}\text { Sum of } \\
\text { Squares }\end{array}$ & $\overline{\mathrm{df}}$ & $\begin{array}{l}\text { Mean } \\
\text { Square } \\
\end{array}$ & $\bar{F}$ & Sig. \\
\hline \multirow{3}{*}{1} & Regression & 2890.585 & 5 & 578.117 & 12.129 & .000 \\
\hline & Residual & 4480.575 & 94 & 47.666 & & \\
\hline & Total & 7371.160 & 99 & & & \\
\hline
\end{tabular}

a. dependent variable: Profitability 
b. predictors: (constant), Risk coverage control measures, credit control measures, asset coverage control measures, liquidity control measures, obligatory reserve measures

Thus the means are significantly different and we decide that the effects are real and we can now accept the first hypothesis that says that there would be financial performance if practices of COBAC control measures would be implemented.

THE MODEL IS WRITTEN AS

$\mathrm{Y}_{\mathrm{P}(1 \mathrm{t})}=\beta_{0}+\beta_{11} \mathrm{X}_{\mathrm{RCCM}(1 \mathrm{t})}+\beta_{12} \mathrm{X}_{\mathrm{CCM}(2 \mathrm{t})}+\beta_{13} \mathrm{X}_{\mathrm{ACCM}(3 \mathrm{t})}+\beta_{14} \mathrm{X}_{\mathrm{LCM}(4 \mathrm{t})}+\beta_{15} \mathrm{X}_{\mathrm{ORM}(5 \mathrm{t})}+\mu_{1 \mathrm{t}}$

$\breve{y}_{\mathrm{FP}(1 t)}=9.6641+(-0.445) \mathrm{X}_{\mathrm{RCCM}(1 \mathrm{t})}+1.593 \mathrm{X}_{\mathrm{CCM}(2 t)}+0.173 \mathrm{X}_{\mathrm{ACCM}(3 t)}+(-.066) \mathrm{X}_{\mathrm{LCM}(4 t)}+1.249 \mathrm{X}_{\mathrm{ORM}(5 t)}+\mu_{1 \mathrm{t}}$

From the table above, we can see that COBAC control measures is related to financial performance, Credit Control Measures and Obligatory Reserve Measures are positively related to financial performance. According to this relation, the less the risk involved in projects the more the profitability of the project according to the respondents. Whenever the MFI has a good credit control and diversification plan and a better monitoring of its projects then financial strength can be achieved. We thus accept the first hypothesis.

We can also easily see from the analysis that the Asset Coverage Control Measures (ACCM) and Liquidity Control Measures (LCM) were not properly implemented and as such those measures are not significant and thus do not have any influence on the performance of the MFIs. This reinforces the fact that most MFIs have not implemented all of the COBAC control measues and when they do implement, they are fully implemented.

The Model Two

Table 4.5.3: ANOVA for model two

\begin{tabular}{llccccc}
\hline \hline Model & & $\begin{array}{l}\text { Sum of } \\
\text { Squares }\end{array}$ & Df & Mean Square & F & Sig. \\
\hline \multirow{2}{*}{2} & Regression & 1955.400 & 5 & 391.080 & 8.560 & $\mathbf{. 0 0 0}^{\mathbf{b}}$ \\
& Residual & 4294.640 & 94 & 45.688 & & \\
& Total & 6250.040 & 99 & & & \\
& & & & & & \\
\end{tabular}

a. dependent variable: customer satisfaction

b. predictors: (constant), Risk coverage control measures, credit control measures, asset coverage control measures, liquidity control measures, obligatory reserve measures.

A. Dependent variable: customer satisfaction

$\mathrm{Y}_{\mathrm{CS}(1 \mathrm{t})}=\beta_{0}+\beta_{11} \mathrm{X}_{\mathrm{RCCM}(1 \mathrm{t})}+\beta_{12} \mathrm{X}_{\mathrm{CCM}(2 \mathrm{t})}+\beta_{13} \mathrm{X}_{\mathrm{ACCM}(3 \mathrm{t})}+\beta_{14} \mathrm{X}_{\mathrm{LCM}(4 \mathrm{t})}+\beta_{15} \mathrm{X}_{\mathrm{ORM}(5 \mathrm{t})}+\mu_{1 \mathrm{t}}$

$\left.\check{y}_{\mathrm{CS}(1 \mathrm{t})}=5.687+0.079 \mathrm{X}_{\mathrm{RCCM}(1 \mathrm{t})}+(-0.179) \mathrm{X}_{\mathrm{CCM}(2 \mathrm{t})}+(0.091) \mathrm{X}_{\mathrm{ACCM}(3 t)}+(-.203)\right) \mathrm{X}_{\mathrm{LCM}(4 t)}+1.213 \mathrm{X}_{\mathrm{ORM}(5 \mathrm{t})}+\mu_{1 \mathrm{t}}$

Looking at the information above, we can say that Liquidity Control Measures and Obligatory Reserve Measures have significantly has an impact on customer satisfaction. As seen above the more the Liquidity Control Measures, the more the customer satisfaction and the more the Obligatory Reserve Measures are respected, the more the customers would be satisfied According to the responses 
We can also easily see from the analysis that the risk coverage ratio, credit control ratio and Asset Coverage Control Measures (ACCM) were not properly implemented and as such those measures are not significant and thus do not have any influence on the performance of the MFIs This also goes to reinforces the fact that most MFIs have not implemented all of the COBAC control measues and when they do implement, they are fully implemented. There is need for these MFIs to put in place all the measures to reep all the potential benefits.

TABLE 4.5.5: ANOVA FOR MODEL THREE

\begin{tabular}{lllcccc}
\hline \hline Model & & $\begin{array}{l}\text { Sum of } \\
\text { Squares }\end{array}$ & df & Mean Square & F & Sig. \\
\hline \multirow{3}{*}{3} & Regression & 4876.185 & 5 & 975.237 & 18.259 & $\mathbf{. 0 0 0}^{\mathbf{b}}$ \\
& Residual & 5020.565 & 94 & 53.410 & & \\
& Total & 9896.750 & 99 & & & \\
& & & & & & \\
\hline \hline
\end{tabular}

a. dependent variable: loan performance

b. predictors: (constant), Risk coverage control measures, credit control measures, asset coverage control measures, liquidity control measures, obligatory reserve measures

$\mathrm{Y}_{\mathrm{P}(1 \mathrm{t})}=\beta_{0}+\beta_{11} \mathrm{X}_{\mathrm{RCCM}(1 \mathrm{t})}+\beta_{12} \mathrm{X}_{\mathrm{CCM}(2 \mathrm{t})}+\beta_{13} \mathrm{X}_{\mathrm{ACCM}(3 \mathrm{t})}+\beta_{14} \mathrm{X}_{\mathrm{LCM}(4 \mathrm{t})}+\beta_{15} \mathrm{X}_{\mathrm{ORM}(5 \mathrm{t})}+\mu_{1 \mathrm{t}}$

$\left.\breve{y}_{\mathrm{FP}(1 \mathrm{t})}=5.687+0.079 \mathrm{X}_{\mathrm{RCCM}(1 \mathrm{t})}+(-0.179) \mathrm{X}_{\mathrm{CCM}(2 \mathrm{t})}+(0.091) \mathrm{X}_{\mathrm{ACCM}(3 \mathrm{t})}+(-.203)\right) \mathrm{X}_{\mathrm{LC} \mathrm{M}(4 \mathrm{t})}+1.213 \mathrm{X}_{\mathrm{ORM}}$ $(5 t)+\mu_{1 t}$

\begin{tabular}{|l|c|c|}
\hline (RCCM) & 0.002 & $<0.05$ \\
\hline$($ CCM $)$ & 0.000 & $<0.05$ \\
\hline$($ ACCM) & 0.000 & $<0.05$ \\
\hline$($ LCM $)$ & 0.020 & $<0.05$ \\
\hline$($ ORCM) & 0.000 & $<0.05$ \\
\hline
\end{tabular}

From the analysis above, we can see that Risk coverage control measures, credit control measures, asset coverage control measures, liquidity control measures, obligatory reserve measures are positively correlated to loan performance.

\section{Summary Of Findings, Conclusion And Recommendations}

This chapter consists of research summary findings, conclusion, recommendation and suggested areas for further research.

\section{Summary of Findings}

Summary of research findings revealed no significant relationship between source of information and the notion of MFIs with reference to MFIs customers' perception. Again, there exist no significant 
relationship between various type of savings and voluntary saving following analysed information obtained from MFIs customers. Thus, voluntary savings was the main form of savings. Findings revealed that, customers often deposits cash mostly during months end and was the popular form of transaction and, most customers had access to credit facilities following loan application. Majority of applied loan often last from 1month-3months mostly for home keeping activities, business activities and payment of children school requirements. However, proof of physical collateral was the popular form collateral presented to authorities before loan approval. A good number of respondents affirmed in prompt payment of loan most having obtained loan less than one hundred thousands FCFA.

It was envisaged that majority of respondents strongly agreed that MFIs are essential for socio-economic development. COBAC control mechanism in terms of prudential and non-prudential norms revealed that majority customers of MFIs within study area often encountered problems of high interest rate on loan, ccommunication gaps and inadequate awareness, limited management and slow action to services.

At a 5\% significant level, a significant strong relationship existed between location and impact of COBAC regulations on MFIs according to authorities. Thus, supervisory authorities and institutions to certify MFIs in Cameroon makes the sector to remains fragile and suffers from disorder that makes it difficult to control, challenges in realizing collateral from customers among others.

\section{Conclusion On The Models}

\section{Conclusion on model one}

\section{cobac control measures and profitability of MFIs}

$$
\breve{y}_{\mathrm{FP}(1 \mathrm{t})}=9.6641+(-0.445) \mathrm{X}_{\mathrm{RCCM}(1 \mathrm{t})}+1.593 \mathrm{X}_{\mathrm{CCM}(2 \mathrm{t})}+0.173 \mathrm{X}_{\mathrm{ACCM}(3 \mathrm{t})}+(-.066) \mathrm{X}_{\mathrm{LCM}(4 t)}+1.249 \mathrm{X}_{\mathrm{ORM}(5 t)}+\mu_{1 \mathrm{t}}
$$

\begin{tabular}{|l|l|l|l|}
\hline$($ RCCM $)$ & 0.045 & $<0.05$ & significant \\
\hline$($ CCM $)$ & 0.002 & $<0.05$ & significant \\
\hline$($ ORM $)$ & 0.001 & $<0.05$ & significant \\
\hline
\end{tabular}

The person in charge should weigh carefully the information obtained and arrive at a judgment as to the credit quality of the loans under review. Each loan is appraised on the basis of its own characteristics. Consideration is given to the risk involved in the project being financed; the nature and degree of collateral security; the character, capacity, financial responsibility, and record of the borrower; and the feasibility and probability of its orderly liquidation in accordance with specified terms.

The willingness and ability of a debtor to perform as agreed remains the primary measure of a loan's risk. This implies that the borrower must have earnings or liquid assets sufficient to meet interest payments and provide for reduction or liquidation of principal as agreed at a reasonable and foreseeable date. However, it does not mean that borrowers must at all times be in a position to liquidate their loans, for that would defeat the original purpose of extending credit.

Following analysis of specific credits, it is important that the examiner ascertain whether troublesome loans result from inadequate lending and collection policies and practices or merely reflect exceptions to basically sound credit policies and practices.

The efficiency of management of the MFIs involved was not significant and Analysts often regard the quality of MFI management as the most important factor in determining whether an MFI fails or survives. This new idea considers a bank's essential financial intermediation functions (that is, attracting deposits to make loans and investments) to require a measure of efficiency. Siems' analysis confirms that management's role is important to a bank's survival

We can also conclude this model by saying that the Asset Coverage Control Measures (ACCM) and Liquidity Control Measures (LCM) were not properly implemented and as such those measures are not 
significant and thus do not have any influence on the performance of the MFIs. The MFIs should implement these control measures to be performant.

\section{Conclusion on model two}

\section{COBAC control measures and customer satisfaction}

$\left.\breve{\mathbf{y}}_{\mathrm{CS}(1 \mathrm{t})}=5.687+0.079 \mathrm{X}_{\mathrm{RCCM}(1 \mathrm{t})}+(-0.179) \mathrm{X}_{\mathrm{CCM}(2 \mathrm{t})}+(0.091) \mathrm{X}_{\mathrm{ACCM}(3 \mathrm{t})}+(-.203)\right) \mathrm{X}_{\mathrm{LCM}(4 \mathrm{t})}+1.213 \mathrm{X}_{\mathrm{ORM}(5 \mathrm{t})}+\mu_{1 \mathrm{t}}$

\begin{tabular}{|l|l|l|l|}
\hline$($ LCM $)$ & 0.000 & $<0.05$ & significant \\
\hline$($ ORM $)$ & 0.001 & $<0.05$ & significant \\
\hline
\end{tabular}

In order to satisfy clients or members, MFIs must know what the clients or customers want. They should always listen to the needs of their clients and expectations. Client or member satisfaction refers to all client expectations combined with the quality of service

Risk coverage is crucial for customer satisfaction and so the MFI must monitor their credit activities. The liquidity needs should be reviewed on a periodic basis. For most banks, this will mean at least on a weekly basis. This review should encompass a detailed forecast of imminent liquidity requirements and a broad projection of cash needs for the next three month period. Monitoring goes along side with Reporting which enables the gathering of information to be used in making decisions for improving credit performance and profitability.

We can also conclude this model by saying that the risk coverage measure, credit control measure and Asset Coverage Control Measures (ACCM) were not properly implemented and as such those measures are not significant and thus do not have any influence on the performance of the MFIs. The MFIs should implement these control measures to be performant

\section{Conclusion on model three}

$\left.\breve{y}_{\mathrm{FP}(1 \mathrm{t})}=5.687+0.079 \mathrm{X}_{\mathrm{RCCM}(1 \mathrm{t})}+(-0.179) \mathrm{X}_{\mathrm{CCM}(2 \mathrm{t})}+(0.091) \mathrm{X}_{\mathrm{ACCM}(3 \mathrm{t})}+(-.203)\right) \mathrm{X}_{\mathrm{LC} \mathrm{M}(4 t)}+1.213 \mathrm{X}_{\mathrm{ORM}(5 \mathrm{t})}+\mu_{1 \mathrm{t}}$

\begin{tabular}{|l|c|c|}
\hline RCCM) & 0.002 & $<0.05$ \\
\hline (CCM) & 0.000 & $<0.05$ \\
\hline ACCM) & 0.000 & $<0.05$ \\
\hline (LCM) & 0.020 & $<0.05$ \\
\hline (ORCM) & 0.000 & $<0.05$ \\
\hline
\end{tabular}

we can see from the analysis that Risk coverage control measures, credit control measures, asset coverage control measures, liquidity control measures, obligatory reserve measures are positively correlated to loan performance. We can thus encourage the MFIs to continue implementing these strategies to better meet customers of clients.

\section{Implication Of Results}


Respecting the the control measures put in place by COBAC enables MFIs make provision of savings, credit, insurance facilities that can enable the poor to smooth their consumption, manage their risk better, gradual build their asset base, develop their microenterprises, enhance their income generating activities, enjoy and improve quality life towards poverty reduction. From the analysis, we can see that COBAC control measures is related to financial performance, Credit Control Measures and Obligatory Reserve Measures are positively related to financial performance. According to this relation, the less the risk involved in projects the more the profitability of the project according to the respondents. Which implies whenever a MFI has a good credit control and diversification plan and a better monitoring of its projects then financial strength can be achieved? We can also easily see from the analysis that the Asset Coverage Control Measures (ACCM) and Liquidity Control Measures (LCM) were not properly implemented and as such those measures are not significant and thus do not have any influence on the performance of the MFIs. This reinforces the fact that most MFIs have not fully implemented all of the COBAC control measures and when they do implement, the only outcome is performance of the structure.

\section{Final Conclusion}

The research raises series of prudential and non-prudential norms used by COBAC to regulate the activities of MFIs. Thus, study objectives were achieved by identifying various problems pledging COBAC control norms on MFIs within the study area. This was achieved by addressing challenges affecting each of the specific objective which joined together to address the global objective and coming out with a proposed framework for the regulations on MFIs in Cameroon and other CEMAC states. Based on above summary findings, conclusively, COBAC control regulations on MFIs within study region are averagely managed. they is Need for COBAC to frequently updates prudential and non-prudential regulations and followed by serious monitoring and evaluation of MFIs activities especially those that reject/operates without these regulations.

\section{References}

[1] Achille J.F. and Josephine S.M.T. (2016), Factors influencing loan repayment by credit beneficiaries of microfinance institutions in the Far North region, Cameroon. Available at:http://cyberleninka.ru/article/n/factors-influencing-loan-repayment-by-credit-beneficiaries-ofmicrofinance-institutions-in-the-far-north-region-cameroon.

[2] Alexander F. (2011), the impact of MFL on the Livelihoods of women in rural communities: Case study of Jaman South District, Ghana. A thesis submitted to the institute of distance learning in partial fulfillment for the requirements for the degree of Common Wealth Executive Master in Business Administration. Available at: http://etd.uwc.ac.za/xmlui/bitstream/handle/11394/1899/Sheraton_MCOM_2004.pdf?sequence=1.

[3] Aliyu M. (2013), analysis of the Rolie of Microfinance Banks in Financing of Micro Enterprises in Kaduna State, Nigeria. Department of Business of Business Administration College of Business and Management Studies Kaduna Polytechnic, Kaduna, Ph.D. Available: http://www.ijebf.com/IJEBF_Vol.\%201,\%20No.\%2011,\%20December\%202013/Analysis\%20of\%2 0the\%20Role.pdf

[4] Anne.Lucie L., Jennifer I., Patricia M., and Matthew B. (2005),Overview of the Outreach and Financial Performance of Microfinance Institutions in Africa. Availableat: http://afraca.org/?wpfb_dl=92.

Armel K., Jennifer A., Henok

http://fic.wharton.upenn.edu/fic/africa/Cameroon\%20Final.pdf

[6] Aryeetey (2008) From Informal Finance to Formal Finance in Sub-Saharan Africa: Lessons from Linkage Efforts, Paper presented at the seminar on African Finance for the 21st Century, organized by the IMF Institute in collaboration with the Joint Africa Institute Tunis, Tunisia, March 4-5, 2008

[7] Bernanke, Ben S., Thomas Laubach, Adam S. Posen and Frederic S. Mishkin (1999). Inflation Targeting: Lessons from the International Experience. Princeton, NJ: Princeton University Press.

[8] Besong B.A.(2012), the Cameroonian Banking and Financial Sector.j Cameroon Ministry of Finance . Available at:https://www.um.edu.mt/_data/assets/pdf_file/0006/153267/cameroon.pdf.

[9] Bank, W. (2012). A Guide to regulating and supervising MFLs . CGAP: CGAP/World Bank.

[10] Sayed S.A.S., I. B. (2013). Conceptual Framework, the role of Microfinance on the well being of th poor people. Case studies from Malysia and Yemen. Asian social science, , Volume. 10, No, 1; 2014, 231. 
[11] Cameroon Ministry of Economy, Planning and Regional Development (2013), Economic development report of Cameroon, North West Region. P. 12-13

[12] Cameroon National Institute of Statistics (2011) youths and labor market in Cameroon 2010. P.10

[13] Cameroon National Institute of Statistics( 2009), Annual statistics of Cameroon.

[14] COBAC (2009). Report du Marche Bancaire et Microfinance Camerounaise. European Commission( 2003) Microcredit for small businesses and business creation: Bridging market gap. Bruxelles: Enterprise publication.

[15] Claire R. (2009), Cool Head, Warm Heart: Governance and the Mission of Microfinance in the Case of MC2Micro-Banks, Cameroon. Available at:http://digitalcollections.sit.edu/cgi/viewcontent.cgi?article=1730\&context=isp_collection.

[16] Denis L.M.D (2010), the Role of Regulation and Supervision of Microfinance Institutions: Evidence From South Africa, and Its Implications For The Development of Non-Deposit Taking Microfinance Regulation In Kenya. Master Of Science, University Of Bergamo, Italy, School Of Economics And Business Studies. Available at http://www.universitymeetsmicrofinance.eu/uploads/2/5/8/2/25821214/thesis_muganga.pdf

[17] Djoum K. S.(2008), Mutuelle Communautaire de Croissance (MC2s), Cameroon: Decentralized Community Banks for Remote Outreach. Organisation of the Microfinance Sector in Cameroon. Available at:http://www.coady2.stfx.ca/tinroom/assets/file/ford/docs/Coady_Cameroon_Final.pdf.

[18] Evers,\& Jung. (2007). Status of microfinance in Western Europe -an academic review. EMN Issue Paper

[19] Fombon R.M. (2011), Regulatory Framework \& SACCO Development - Cameroon. "Attaining Sustainable SACCO Growth using Regulation Framework'. Cameroon Cooperative Credit Union League Limited (CamCCUL).

[20] Gerald E,(2005)Central Banks as Agents of Economic Development. Availablehttp://scholarworks.umass.edu/cgi/viewcontent.cgi?article=1083\&context=peri_workingpa pers 01, January 2016>

[21] Gerald E. (2005)Central Banks as Agents of Economic Development. Available at:http://scholarworks.umass.edu/cgi/viewcontent.cgi?article=1083\&context=peri_workingpapers $<$ A ccessed 01, January 2016>

[22] Gilbert A.A.(n.d), a critical look at banking sector regulations in Cameroon. http://www.econrsa.org/system/files/workshops/papers/2012/akon-banking-sector.pdf

[23] Ian L. (2009)Perceptions of Microfinance in Cameroon: A Case Study of UNICS, Yaoundé. Available

at:http://digitalcollections.sit.edu/cgi/viewcontent.cgi?article=1731\&context=isp_collection

[24] IMF (2009), Cameroon: Financial System Stability Assessment-Update, IMF Country Report No. 09/51 February 2009.

[25] J. Mukama, T. Fish and J. Volschenk(2005), problems affecting the growth of MFLs in Tanzania. Available

at: http://www.academia.edu/4712582/PROBLEMS_AFFECTING_THE_GROWTH_OF_MICROFIN ANCE_INSTITUTIONS_IN_TANZANIA_INTRODUCTION

[26] Joseph N., Leopold D.W., Alain T.N.(2013), determing loan delinquency in urban MFL in Cameroon.

http://savingsanddevelopment.unibg.it/wordpress/wpcontent/themes/SavingsAndDevelopment/pdf/04\%20WAMBA\%202015\%20DEF.pdf

[27] Kouassi, A, Akpapuna, J \& Soededje, H. 2007. An overview of the banking sector in Cameroon.

[28] Kouassi, A, Akpapuna, J and Soededje, H. (2007). An overview of the banking sector in Cameroon.

[29] Lafourcade, A.L., Isern, J., Mwangi, P. Brown M. (2005) Overview of the outreach and financial performance of microfinance institutions in Africa. Microfinance Information exchange, Washington, DC. Availableat: www.mixmarket.org.

[30] Lairap J. (2004), the disciplinary power of microfinance : some preliminary evidence from Cameroon. PhD thesis. Faculty FMG: Amsterdam Institute for Social Science Research (AISSR). Available at:http://dare.uva.nl/document/2/49659. 
[31] Lämmermann, S. (2010). Microcredit in France: Financial support for social inclusion. In B. J. Carboni, M. L. Calderón, S. R. Garrido, K. Dayson, \& J. Kickul, Handbook of Microcredit in Europe(pp. 36-60). Edward Elgar.

[32] Lämmermann, S. (2010). Microcredit in France: Financial support for social inclusion. In B. J. Carboni, M. L. Calderón, S. R. Garrido, K. Dayson, \& J. Kickul, Handbook of Microcredit in Europe(pp. 36-60). Edward Elgar

[33] Leonard A. F.(2012), the Microfinance market of Cameroon. http://www.microfinancegateway.org/sites/default/files/mfg-en-paper-the-microfinance-market-ofcameroon-analyzing-trends-and-current-developments-mar-2012.pdf

[34] Leonard A.F, (2012), the Microfinance Market of Cameroon. Analyzing trends and current development. Available at:http://www.microfinancegateway.org/sites/default/files/mfg-en-paper-themicrofinance-market-of-cameroon-analyzing-trends-and-current-developments-mar-2012.pdf.03, January 2016>

[35] Leonard A.F. (2012), the Microfinance Market of Cameroon. Analyzing trends and current development. Available at:http://www.microfinancegateway.org/sites/default/files/mfg-en-paper-themicrofinance-market-of-cameroon-analyzing-trends-and-current-developments-mar-2012.pdf.

<Accessed 03, January 2016>

[36] Littlefield E., Jonathan M., Syeh H.(2003), Is Microfinance and Effective Strategy to Reach the MDG's?

[37] Mamouda M. (2009), the regulatory landscape of Microfinance in the CEMAC Region. Available at: //www.microfinancegateway.org/sites/default/files/mfg-en-paper-the-regulatory-landscape-ofmicrofinance-in-the-cemac-region-jul-2009_0.pdf.

[38] Michael S. ( n.d) Income, Institutions, and Saving Performance in Individual Development Accounts. Washington University in St. Louis Mark Schreiner, Washington University in St. Louis Sondra Beverly, University of Kansas. http://www.microfinance.com/English/Papers/IDAs_Income.pdf

[39] Micro World, (2010-2016) About Microcredit. http://www.microworld.org/en/aboutmicroworld/about-microcredit

[40] MicroRate(2013)MicrofinanceInstitutionTierDefinitions. Availableat: http://www.microrate.com/media/downloads/2013/04/MicroRate-White-paper-MicrofinanceInstitution-Tier-Definitions.pdf

[41] Ministry of public health (2000-2009), North West Province syntheis report for the national concensus of the national health development plan period 2000-2009. Available at: http://minsantecdnss.cm/sites/minsante-cdnss.cm/files/biblio/2011/partb-2000-02-

mspnoouprovsynthesisreportforthenationalconcensusonthenationalhealthdevplan.pdf

[42] Mishkin (1999). Inflation Targeting: Lessons from the International Experience. Princeton, NJ: Princeton University Press.

[43] Mokoro, J. M., Nyaoga, R. M., Magutu, P. O., Khoya, O. M., \&Onsongo, C. O. (2010).The transition from micro- finance into formal banking among the micro finance institutions in Kenya. School of Business, Department of Accounting and Finance: University of Nairobi.

[44] Motova D. (2006), "Microfinance and Poverty Alleviation, a case study of Uganda finance trust." GoteborgUniversity, Microfinancefrom Argentina, Developmentpolicyreview. P. 339-354

[45] Muhammad, S. (2010).MicrofinanceChallenges and Opportunities in Pakistan. European Journal of Social Sciences -Volume 14, Number 1

[46] National de Microfinance. Yaoundé: Ministère de l'Economie et des Finance : unité de coordination du projet.

[47] Ngolle N.(2014), Sun Newspaper. Biya's Vision 2035 is realistic. available at : http://www.cameroonweb.com/CameroonHomePage/NewsArchive/Biya-s-Vision-2035-is-realisticProf-Ngolle-Ngolle-314146

[48] Olayiwola, A. M.,Eludoyin, A. O and Ekecha, A. E. (2011)Land Use Change in the Mezam Division of the North-West Province, Cameroon From Landsat Imageries (1988 And 2001) Ethiopian Journal of Environmental Studies and Management Vol. 4 No.1 2011. Available at:http://www.ajol.info/index.php/ejesm/article/viewFile/67201/55302 
[49] Onsongo, C. O. (2010). The transition from micro- finance into formal banking among the micro finance institutions in Kenya. School of Business, Department of Accounting and Finance: University of Nairobi.

[50] Renée C.B.(2008) Regulation and Supervision of Member-Owned Institutions in Remote Rural Areas. Available at: http://www.pamiga.org/pdf/pdf-para247-pamiga-1234634368.pdf

[51] République du Cameroun. (2002). Projet d'appui au Programme

[52] Rhyne, E. (2001) Mainstreaming microfinance: How Lending to the Poor Began, Grew, and Came of Age in Bolivia. Bloomfield:KumarianPress CT.

[53] Ricardo G, (2014)Institutional Challenges for Effective Banking Regulation and Supervision in Sub-Saharan Africa.http://www.odi.org/sites/odi.org.uk/files/odi-assets/publications-opinionfiles/9280.pdf.<Accessed 03, January 2016>

[54] Ricardo G. (2014) Institutional Challenges for Effective Banking Regulation and Supervision in Sub-Saharan Africa. Available at: https://www.odi.org/sites/odi.org.uk/files/odi-assets/publicationsopinion-files/9280.pdf

[55] Ricardo G. (2014),Institutional Challenges for Effective Banking Regulation and Supervision in Sub-Saharan Africa. Available at:http://www.odi.org/sites/odi.org.uk/files/odi-assets/publicationsopinion-files/9280.pdf. <Accessed 03, January 2016>

[56] Rim B. and Cherif R. (2014). Commercial banks in Microfinance: entry strategies and key of success.

Available: athttp://businessperspectives.org/journals_free/imfi/2014/imfi_en_2014_01cont_\%20Bounouala.pdf

[57] Sayed S.A.S., I. B. (2013). Conceptual Framework, the role of Microfinance on the well being of th poor people. Case studies from Malysia and Yemen. Asian social science, , Volume. 10, No, 1; 2014, 231. Available at:

[58] Shari B. and Craig C. (n.d)REGULATION AND SUPERVISION OF MICROFINANCE INSTITUTIONS Experience from Latin America, Asia, and Africa. The Microfinance Network Occasional Paper No. 1. Available at:http://www.microfinancegateway.org/sites/default/files/mfgen-paper-the-regulatory-landscape-of-microfinance-in-the-cemac-region-jul-2009 0.pdf. <Accessed 02, January 2016>

[59] Shari B. and Craig C. (n.d)REGULATION AND SUPERVISION OF MICROFINANCE INSTITUTIONS Experience from Latin America, Asia, and Africa. The Microfinance Network Occasional Paper No. http://www.microfinancegateway.org/sites/default/files/mfg-en-paper-theregulatory-landscape-of-microfinance-in-the-cemac-region-jul-2009_0.pdf. <Accessed 02, January 2016>

[60] Shaven W.B. (2015), A study of accounting and accountability practices in MFLs: Case evidence from Cameroon. A thesis submitted to the University of Birmingham for the degree of Doctor of Philosophy. Department of Accounting Birmingham Business Sciences University of Birmingham. Available at:http://etheses.bham.ac.uk/6008/1/Sha'ven15PhD.pdf. Accessed "

[61] Suinyuy D.N.(2013), The Socioeconomic and Environmental Implications of Urban Sprawl on the Coastline of Douala-Cameroon. Options for Integrated Coastal Management. Xiamen University (Coastal and Ocean Management Institute), Master's thesis. Available at: http://www.grin.com/en/ebook/269019/the-socioeconomic-and-environmental-implications-of-urban-sprawl-on-the

[62] Sulaiman D.M.(2010) Microfinance Challenges and Opportunities in Pakistan Available at: https://www.microfinancegateway.org/sites/default/files/mfg-en-paper-microfinance-challenges-andopportunities-in-pakistan-2010.pdf

[63] UNO (2013), Microfinance in Africa.

http://www.un.org/en/africa/osaa/pdf/pubs/2013microfinanceinafrica.pdf

[64] UNO (2015) Sustainable Development Goals: What you need to know. Available at:https://www.opencanada.org/features/sustainable-development-goals-what-you-need-to-know/. $<$ Accessed 03, January 2016>

[65] UNO, (2015) Sustainable Development Goals: What you need to know. https://www.opencanada.org/features/sustainable-development-goals-what-you-need-to-know/. 03, January 2016>

[66] World Bank (2006), good practice guidelines for funders of microfinance. 
http://www.aecid.es/Galerias/fonprode/descargas/Documentos_de_interes_2._Good_Practice_Guidel ines.pdf. 